\title{
Pengetahuan Wanita Usia Subur Tentang Kanker Serviks Dengan Perilaku Pemeriksaan Deteksi Dini Menggunakan IVA
}

\author{
Knowledge of Fertile Age Women About Cervical Cancer With \\ Behavior Early Detection Examination Using IVA \\ Sitti Mukarramah, Subriah, Wirawati Amin, Humrah \\ Poltekkes Kemenkes Makassar \\ (email penulis korespondensi : Sitti_Mukarramah@poltekkes-mks.ac.id)
}

\begin{abstract}
Cervical cancer is the number one killer of women in the world caused by the Human Papilomma Virus. One of the early detection of cervical cancer by checking Visual Inspection with Acetic Acid (VIA) is a simple way to detect cervical abnormalities. Knowledge of cervical cancer is one of the factors influencing WCBA behavior in conducting VIA examinations. This study aims to determine the relationship between WUS knowledge on cervical cancer with early detection examination behavior using VIA in Maradekaya Village. The research sample was 59 respondents with random sampling technique and a cross-sectional research design. The results showed that the respondents' knowledge about cervical cancer was included in the "tofu" category as many as 55 respondents (93.2\%) and "do not know" category were 4 respondents (6.8\%), respondents who did VIA examination were 22 respondents (37.3\%) and those who did not perform VIA examination were 37 respondents (62.7\%). Chi-square test with $95 \%$ CI showed a p-value of $0.521(P>0.05)$. These results indicate that there is no relationship between WCBA knowledge about cervical cancer with early detection using VIA in Maradekaya Village. Additional conclusions that can influence behavior it is culture.
\end{abstract}

Keywords: Cervical Cancer, Knowledge, Behavior

\begin{abstract}
ABSTRAK
Kanker serviks adalah pembunuh wanita nomor satu di dunia yang disebabkan oleh Human Papilomma Virus. Salah satu deteksi dini kanker serviks dengan pemeriksaan Visual Inspection with Acetic Acid (VIA) merupakan cara sederhana untuk mendeteksi kelainan serviks. Pengetahuan tentang kanker serviks merupakan salah satu faktor yang mempengaruhi perilaku WCBA dalam melakukan pemeriksaan VIA. Penelitian ini bertujuan untuk mengetahui hubungan antara pengetahuan WUS tentang kanker serviks dengan perilaku pemeriksaan deteksi dini menggunakan VIA di Desa Maradekaya. Sampel penelitian sebanyak 59 responden dengan teknik random sampling dan desain penelitian cross-sectional. Hasil penelitian menunjukkan bahwa pengetahuan responden tentang kanker serviks termasuk dalam kategori "tahu" sebanyak 55 responden $(93,2 \%)$ dan kategori "tidak tahu" sebanyak 4 responden $(6,8 \%)$, responden yang melakukan pemeriksaan VIA sebanyak 22 responden. responden $(37,3 \%)$ dan yang tidak melakukan pemeriksaan VIA sebanyak 37 responden (62,7\%). Uji Chi-square dengan 95\% CI menunjukkan nilai p 0,521 (P>0,05). Hasil ini menunjukkan bahwa tidak ada hubungan antara pengetahuan WCBA tentang kanker serviks dengan deteksi dini menggunakan VIA di Desa Maradekaya. Kesimpulan tambahan yang dapat mempengaruhi perilaku itu adalah budaya.
\end{abstract}

Kata Kunci: Kanker Serviks, Pengetahuan, Perilaku 
Available Online at http://journal.umgo.ac.id/index.php/madu

\section{PENDAHULUAN}

Wanita memiliki peran yang cukup penting dalam sebuah keluarga, sehingga kesehatan wanita juga begitu penting. Kesehatan merupakan hal yang harus diupayakan dan dijaga agar seseorang dapat mencapai kualitas hidup yang baik. Salah satu masalah kesehatan yangpenting bagi wanita adalah kesehatanreproduksi. Kesehatan reproduksi merupakan bidang kesehatan yang khusus mempelajari hal-hal yang berkaitan dengan kandungan seorang wanita, salah satunya adalah tumor dan kanker serviks. ${ }^{1}$

Kanker serviks merupakan masalah kesehatan utama bagi masyarakat di seluruh dunia dan merupakan pembunuh wanita nomor satu di dunia. Kanker serviks terjadi karena tumbuhnya sel-sel abnormal pada jaringan leher rahim yang nantinya akan menjadi suatu penyakit keganasan pada serviks uteri. Namun, kanker serviks merupakan penyakit yang dapat dicegah dan dideteksi sedini mungkin. Menurut data dari World Health Organization (WHO) memperkirakan bahwa sekitar 500.000 kasus kanker leher rahim di diagnosis setiap tahun, terutama dikalangan perempuan di wilayah termiskin di dunia dan sekitar 274.000 perempuan meninggal karena kanker serviks. ${ }^{2}$

Di Asia, setiap empat menit seorang perempuan meninggal karena kanker serviks. Secara global kanker serviks menempati urutan pertama di negara berkem bang sedangkan di negara maju menempati urutan kesepuluh,karenanya pengetahuan tentang deteksi dini kanker serviks sangat penting untuk mengurangi angka kematian yang diakibatkannya. $^{3}$

Terdapat 90-100 kasus kankerserviks per 100.000 penduduk per tahun di Indonesia. ${ }^{4}$ sedangkan data dari Riset Kesehatan Dasar (Riskesdas) menyebutkan bahwa dari 1.027 .763 sampel 522.354 perempuan terdiagnosis terkena kanker serviks. ${ }^{5}$

Data dari Dinas Kesehatan Provinsi Sulawesi Selatan mengemukakan bahwa jumlah penderita kanker serviks terbesar ada di kota Makassar, Kabupaten Gowa, Wajo, Bone dan Luwu Utara. Pada kasus kanker serviks terdapat 109 kasus $(28,4 \%)$ di rumah sakit dan 275 kasus $(71,6 \%)$ di Puskesmas. ${ }^{6}$

Salah satu upaya pengendalian kanker di Indonesia dilakukan melalui upaya deteksi dini sebagai salah satu cara dalam melakukan pencegahan sekunder. Upaya deteksi dini kanker merupakan salah satu tindakan pencegahan sekunder disamping upaya pengobatan sebelum tanda dan gejala kanker muncul. Pada pencegahan kanker serviks tindakan deteksi dini berupa pemeriksaan IVA dan pap smear. $^{7}$

Beberapa faktor risiko terjadinya kanker serviks yaitu pola atau gaya hidup termasuk perilaku seksual dengan jumlah mitra seks dan usia saat pertama kali melakukan seks pervaginal dan riwayat kesehatan reproduksi. Perilaku merawat kebersihan alat kelamin, riwayat penggunaan kontrasepsi dan tingkat pengetahuan perempuan yang terbatasdalam memahami penyebab kanker serviks dan pentingnya melakukan deteksidini. ${ }^{7}$

Ada hubungan tingkat pengetahuan tentang kanker serviks dengan perilaku deteksi dini kanker serviks di wilayah kerja Puskesmas Sangkrah Kelurahan Sangkrah Kecamatan Pasar Kliwon Surakarta dengan nilai $p$-value sebesar $0,017 .^{8}$

Data dari Profil kesehatan Kabupaten Gowa pada tahun 2015 menunjukkan bahwa cakupan deteksi dini kanker serviks menggunakan test IVA dari 3.389 orang wanita yang berumur 30-50 tahun dari 8 puskesmas yang melakukan pemeriksaan IVA hanya sebanyak 1.545 orang yang melakukan test IVA. ${ }^{9}$ Data awal dari Puskesmas Bajeng menunjukkan bahwa dari 837 sasaran wanita usia subur (WUS) pada tahun 2016 hanya 406 orang yang melakukan pemeriksaan IVA dan 3 orang dinyatakan positif, pada tahun 2017 dilakukan sebuah gerakan yang dinamakan bercak IVA sehingga jumlah pemeriksaan dari Januari - Oktober meningkat menjadi 660 orang dan didapatkan 4 orang positif.

Meningkatkan pengetahuan wanita usia subur dapat dilakukan dengan cara melakukan penyu luhan dan komunikasi informasi edukasi (KIE). Semakin tinggi pengetahuan seseorang akan pentingnya pemeriksaan IVA maka akan timbul kesadaran pada diri seseorang untuk melakukan deteksi dini kanker serviks dengan pemeriksaan 
Available Online at http://journal.umgo.ac.id/index.php/madu

IVA. Pengetahuan yang baik tentang pemeriksaan IVA memungkinkan angka kejadian kankerserviks dapat dicegah seoptimal mungkin sebab deteksi dini merupakan skrining yang efektif dengan tingkat akurasi 80-90\%.

Tujuan penelitian ini adalah untuk mengetahui hubungan pengetahuan wanita usia subur tentang kanker serviks dengan perilaku pemeriksaan deteksi dini meng gunakan Inspeksi Visual Asam Asetat (IVA) di Desa Maradekaya wilayah kerja Puskesmas Bajeng Keca matan Bajeng Kabupaten Gowa. Terkait hal tersebut maka penulis tertarik melakukan penelitian mengenai hubungan penge tahuan wanita usia subur tentang kanker serviks dengan perilaku pemeriksaan deteksi dini menggunakan Inspeksi Visual Asam Asetat (IVA) di Desa Maradekaya wilayah kerja Puskesmas Bajeng Kecamatan Bajeng Kabupaten Gowa.

\section{BAHAN DAN METODE}

Jenis penelitian yang digunakan adalah penelitian survey analitik dengan pendekatan cross-sectional. Populasi pada penelitian ini adalah semua wanita usia subur yang ada di wilayah kerja Puskesmas Bajeng Kecamatan Bajeng Kabupaten Gowa yang berjumlah 837 orang dengan sampel sebanyak 59 wanita usia subur (WUS) menggunakan rumus lameshow dengan teknik pengambilan sampel random sampling, instrumen yang digunakan adalah kuesioner dengan pertanyaan tertutup mengenai pengetahuan tentang kanker serviks dan perilaku pemeriksaan IVA dengan teknik pengambilan data primer terkait hal tersebut. Teknik analisis data ada dua tahapan yaitu: analisis univariate untuk meng gambarkan pola data penelitian yang ada serta analisis secara bivariate dengan menggunakan rumus Chi-square dengan CI 95\%. Dengan bantuan software pengolahan data dan disajikan dalam bentuk tabel.

\section{HASIL}

Hasil penelitian ini tertuang dalam tabel di bawah ini dan diuraikan sebagai berikut:

Tabel 1 Distribusi Menurut Karakteristik

\begin{tabular}{lcc}
\hline $\begin{array}{l}\text { Karakteristik } \\
\text { Responden }\end{array}$ & $\begin{array}{c}\text { Jumlah } \\
\text { (n) }\end{array}$ & $\begin{array}{c}\text { Persen } \\
(\%)\end{array}$ \\
\hline \hline Umur & & \\
$\quad<20$ tahun & 3 & 5,1 \\
$20-35$ tahun & 25 & 42,4 \\
$\quad>35$ tahun & 31 & 52,5 \\
Pendidikan & & \\
$\quad$ Tidak Sekolah & 1 & 1,7 \\
$\quad$ Sekolah Dasar & 9 & 15,3 \\
$\quad$ Sekolah Menengah & & \\
Pertama (SMP) & 15 & 25,4 \\
$\quad$ Sekolah Menengah & & \\
Atas (SMA) & 28 & 47,5 \\
Perguruan & 6 & 10,2 \\
Tinggi Pekerjaan & & \\
PNS/TNI/POLRI & 1 & 1,7 \\
Wiraswasta & 3 & 5,1 \\
Karyawan Swasta & 3 & 5,1 \\
Tidak Bekerja & 52 & 88,1 \\
Paritas & & \\
Nulipara & 1 & 1,7 \\
Primipara & 12 & 20,3 \\
Multipara & 46 & 78 \\
\hline \hline
\end{tabular}

Sumber : Data Primer 2018

Berdasarkan tabel di atas menunjukkan bahwa dari 59 reponden, umur rata-rata WUS $>35$ tahun sebanyak 31 orang $(52,5 \%)$, rata-rata berpen didikan SMA sebanyak 28 orang $(47,5 \%)$, jenis pekerjaannya yaitu tidak bekerja sebanyak 52 orang $(88,1 \%)$ dan rata-rata paritas dengan multipara sebanyak 46 orang $(78 \%)$. 
Tabel 2 Distribusi Menurut Umur dan Pe ngetahuan tentang Kanker Serviks

\begin{tabular}{|c|c|c|c|c|c|c|}
\hline \multirow{2}{*}{$\begin{array}{c}\text { Umur } \\
\text { (Tahun) }\end{array}$} & \multicolumn{4}{|c|}{ Pengetahuan } & \multirow[b]{2}{*}{ Total } & \multirow[b]{2}{*}{$\%$} \\
\hline & Tahu & $\%$ & $\begin{array}{c}\text { Tidak } \\
\text { Tahu }\end{array}$ & $\%$ & & \\
\hline$<20$ & 3 & 5,1 & 0 & 0 & 3 & 5,1 \\
\hline $20-35$ & 23 & 39 & 2 & 3,4 & 25 & 42,4 \\
\hline$>35$ & 29 & 49,2 & 2 & 3,4 & 31 & 52,5 \\
\hline Total & 55 & 93,2 & 4 & 6,8 & 59 & 100 \\
\hline
\end{tabular}

Sumber : Data Primer 2018

Berdasarkan tabel di atas menunjukkan bahwa rata-rata responden yang berumur $>35$ tahun sebanyak 31 orang $(52,5 \%)$ dan yang tahu tentang kanker serviks sebanyak 29 orang $(49,2 \%)$

Tabel 3 Distribusi Menurut Pendidikan dan PerilakuTest IVA

\begin{tabular}{|c|c|c|c|c|c|c|}
\hline \multirow{2}{*}{ Pendidikan } & \multicolumn{4}{|c|}{ Perilaku test IVA } & \multirow{2}{*}{ Total } & \multirow{2}{*}{$\%$} \\
\hline & $\mathbf{Y a}$ & $\%$ & Tidak & $\%$ & & \\
\hline Tidak & \multirow{2}{*}{1} & \multirow{2}{*}{1,7} & \multirow{2}{*}{0} & \multirow{2}{*}{0} & \multirow{2}{*}{1} & \multirow{2}{*}{1,7} \\
\hline Sekolah & & & & & & \\
\hline $\mathrm{SD}$ & 3 & 5,1 & 6 & 10,2 & 9 & 15,3 \\
\hline SMP & 8 & 13,6 & 7 & 11,9 & 15 & 25,4 \\
\hline SMA & 7 & 11,9 & 21 & 35,6 & 28 & 47,5 \\
\hline Perguruan & \multirow{2}{*}{3} & \multirow{2}{*}{5,1} & \multirow{2}{*}{3} & \multirow{2}{*}{5,1} & \multirow{2}{*}{6} & \multirow{2}{*}{10,2} \\
\hline Tinggi & & & & & & \\
\hline Total & 22 & 37,3 & 37 & 62,7 & 59 & 100 \\
\hline
\end{tabular}

Sumber : Data Primer 2018

Berdasarkan tabel di atas menunjukkan bahwa rata-rata responden berpendidikan SMA 28 orang $(47,5 \%)$ dan yang melakukan pemeriksaan IVA se banyak 7 orang $(11,9 \%)$.
Tabel 4 Distribusi Menurut Pekerjaan dan PerilakuTest IVA

\begin{tabular}{|c|c|c|c|c|c|c|}
\hline \multirow{2}{*}{ Pekerjaan } & \multicolumn{4}{|c|}{ Perilaku test IVA } & \multirow{2}{*}{ Total } & \multirow{2}{*}{$\%$} \\
\hline & Ya & $\%$ & Tidak & $\%$ & & \\
\hline $\begin{array}{c}\mathrm{PNS} / \mathrm{TNI} / \mathrm{POL} \\
\mathrm{RI}\end{array}$ & 1 & 1,7 & o & o & 1 & 1,7 \\
\hline Wiraswasta & 2 & 3,4 & 1 & 1,7 & 3 & 5,1 \\
\hline $\begin{array}{c}\text { Karyawan } \\
\text { Swasta }\end{array}$ & 1 & 1,7 & 2 & 3.4 & 3 & 5,1 \\
\hline Tidak Bekerja & 18 & 30,5 & 34 & 57,6 & 52 & 88,1 \\
\hline Total & 22 & 37,3 & 37 & 62,7 & 59 & 100 \\
\hline
\end{tabular}

Sumber : Data Primer 2018

Berdasarkan tabel di atas menunjukkan bahwa rata-rata responden tidak bekerja seba nyak 52 orang $(88,1 \%)$ dan yang melakukan pemerik saan IVA sebanyak 18 orang $(30,5 \%)$.

\section{Tabel 5 Distribusi Menurut Pengeta huan}

\begin{tabular}{|c|c|c|}
\hline Pengetahuan & Jumlah (n) & Persen (\%) \\
\hline Tahu & 55 & 93,2 \\
\hline Tidak Tahu & 4 & 6,8 \\
\hline Total & 59 & 100 \\
\hline
\end{tabular}

Sumber : Data Primer 2018

Tabel di atas menunjukkan bahwa dalam penelitian yang dilakukan di Desa Maradekaya, rata - rata responden mengeta hui tentang kanker serviks, dari 59 responden yang diteliti sebanyak 55 orang $(93,2 \%)$ masuk dalam kategori tahu tentang kanker serviks. 
Available Online at http://journal.umgo.ac.id/index.php/madu

Tabel 6 Distribusi Menurut PerilakuTest IVA

\begin{tabular}{ccc}
\hline Test IVA & Jumlah (n) & Persen $(\%)$ \\
\hline YA & 22 & 37,3 \\
Tidak & 37 & 62,7 \\
Total & 59 & 100 \\
\hline
\end{tabular}

Sumber : Data Primer 2018

Berdasarkan tabel di atas menunjukkan bahwa dalam penelitian ini responden rata-rata tidak melakukan test IVA sebanyak 37 orang $(62,7 \%)$, dari 59 responden, yang melakukan test IVA hanya sebanyak 22 orang $(37,3 \%)$.

\section{PEMBAHASAN}

\section{a. Karakteristik Responden}

1) Umur

Umur menunjukkan kondisi kesehatan seseorang yang akan mempengaruhi kebutuhan akses layanan kesehatan dan merupakan salah satu faktor yang mempengaruhi pengetahuan seseorang. ${ }^{10}$ namun pada penelitian yang lain mengemukakan bahwa tidak ada hubungan yang signifikan antara umur dengan pemeriksaan IVA di Puskesmas Talise dengan nilai $p$-value sebesar $1,000 .{ }^{11}$

2) Pendidikan

Hasil penelitian ini menunjukkan bahwa pendidikan tidak berpengaruh terhadap perilaku seseorang namun tidak sesuai dengan hasil penelitian lain yang menyatakan bahwa semakin tinggipendidikan seseorang maka minat untuk melakukan pemeriksaan IVA test semakin tinggi dengan nilai $p$-value $0,01 .^{12}$ dan tingkat pendidikan sangat berpengaruh terhadap pengeta huan ibudalam pembentukan perilaku. ${ }^{13}$

\section{4) Pekerjaan}

Pekerjaan seseorang menyebabkannya meluang kan banyakwaktu untuk bekerja dan bertukar pendapat/pengalamandengan teman di tempat kerjanya namun hal ini tidak sejalan dengan penelitian yang mengemukakan bahwa pekerjaan tidak mempunyai hubungan yangbermakna dengan perilaku WUS dalam deteksi dini kanker serviks dengan metode IVA di Puskesmas TanjungPulu dengan nilai $p$-value $1,000 .{ }^{14}$

5) Paritas

Paritas adalah jumlah kehamilan yang mengha silkan janin yang mampu hidup diluarrahim (28 minggu) namun semakin sering menjalani proses melahirkan maka semakin tinggi resiko terinfeksi virus HPV yang menyebabkan kanker serviks dan sesuai dengan penelitian yang mengemukakan bahwa ada hubungan antara paritas dengan kejadian kanker serviks di Yayasan Kanker. WisnuwardhanaSurabaya dengan nilai p-value $0,000 .{ }^{15}$

b) Pengetahuan WUS tentang serviks

Pengetahuan merupakan hasil dari tahu dan ini terjadi setelah seseorang melakukan penginderaan terhadap suatu obyek tertentu dengan domain kognitif mempunyai 6 tingkatan yakni; (1) Tahu (know), (2) Memahami (comprehension), (3) Aplikasi (aplication), (4) Analisi (analisis), (5) Sintesis (syntesis), (6) Evaluasi (evaluation) dan secara umum tingkat pengetahuan ibu yang ada di Desa Maradekaya dalam kategori "tahu" (C1) belum memahami secara komprehensif sebanyak 59,32\% WUS dan dalam kategori "memahami" (C2) secara komprehensif sebanyak 33,89\% WUS sehingga pengambilan keputusan responden untuk menjalani pemeriksaan deteksi dini kanker serviks menggunakan IVAdipengaruhi oleh pengetahuan yang dimilikinya. ${ }^{13}$ dan deteksi dini kanker serviks dalam penelitian ini adalah tindakan nyata responden dalam usaha pencegahan dini kanker serviks.

c) Perilaku pemeriksaan IVA

Perilaku kesehatan pada dasarnya adalah suatu respon seseorang terhadap stimulus yang berkaitan 
Available Online at http://journal.umgo.ac.id/index.php/madu

dengan sakit dan penyakit, pada sistem pelayanan kesehatan, makanan serta lingkungan. ${ }^{12}$ Faktor faktor yang mempengaruhi perilaku yaitu sikap, pengetahuan, kepercayaan dan tradisi. Dari 85 responden terdapat 58 responden (68\%) tidak melakukan deteksi dini kanker servik dan sebanyak 27 responden (32\%) melakukan deteksi dini kanker serviks sehingga dapat disimpulkan responden yang tidak melakukan deteksi dini kanker serviiks disebabkan karena malu dan tidak ada waktu. ${ }^{9}$

Salah satu hal yang mempengaruhi perilaku seseorang adalah tradisi. Mayoritas responden dalam penelitian ini adalah suku Makassar yang memiliki budaya siri bangunan jiwa yang terdiridari unsur sentimentality (perasaan halus) dan rasa malu, yang berdasarkan nila-nilai luhur manusia, saling menghargai dan menghormati satu dengan lainnya. ${ }^{16}$ Budaya siriee digunakan masyarakat sebagai alasan tidak melakukan pemeriksaan kesehatan terutama pada daerah tubuh mereka yang dianggap tak pantas untuk diperlihatkan pada orang lain sehingga responden jarang dan bahkan tidak pernah melakukan pemeriksaan IVA tersebut.

d) Hubungan Pengetahuan WUS tentang Kanker Serviks dengan Perilaku Pemeriksaan Deteksi Dini Menggu nakan IVA

Pengetahuan merupakan faktor yang penting namun tidak memadai dalam perubahan perilaku kesehatan. Pengetahuan seseorang mengenai kese hatan mungkin penting sebelum perilaku terjadi, tetapi tindakan kesehatan yang diharapkan mungkin tidak akan terjadi kecuali seseorang mempunyai motivasi untuk bertindak atas dasar pengetahuan yang dimilikinya. ${ }^{13}$

Berdasarkan data pada tabel 5 di atas menunjukkan bahwa responden yang tahu dan tidak tahu tentang kanker seviks mayoritas tidak melakukan test IVA. Berdasarkan hasil analisis Uji Chi Square dengan menggunakan uji alternative Fisher Exact pada tingkat kepercayaan 95\% dimana nilai $p$-value 0,521 > 0,05 yang menunjukkan bahwa tidak ada hubungan pengetahuan tentang kanker serviks terhadap pemeriksaan WUS tentang kanker serviks
Responden dengan pengetahuan tentang deteksi dini kanker serviks yang baik akan cenderung memiliki kesadaran yang lebih besar untuk meningkatkan status kesehatannya sehingga lebih besar kemungkinan melakukan pemeriksaan IVA. Namun, pengetahuan yang baik belum tentu membuat seseorang mau secara sadar melakukan pemeriksaan IVA. Hal ini disebabkan oleh berbagai hal diantaranya budaya masyarakat yang mengang gap pemeriksaan pada organ genetalia masih tabu, malu dan takut akan hasil yang diperoleh nantinya. ${ }^{14}$ Faktor sosial budaya sebesar $73 \%$ menjadi faktor hambatan wanita usia subur melakukan Pap smear dan anggota keluarga secara turun-temurun tidak pernah melakukan pemeriksaan Pap smear. Hal tersebut mengindikasikan bahwa tanpa disadari kebudayaan telah mewarnai perilaku anggota keluarga untukmenuruti kebiasaan dalam keluarganya.${ }^{17}$

\section{KESIMPULAN DAN SARAN}

Tidak terdapat hubungan antara pengetahuan wanita usia subur (WUS) tentang kanker serviks dengan perilaku pemeriksaan deteksi dini menggunakan IVA dan salah satu faktor yang mempengaruhi perilaku dalam pemeriksaan tes IVA yaitu budaya. Terkait hal tersebut terdapat beberapa saran yaitu : bagi bidan Puskesmas Bajeng Kab. Gowa dapat menggali faktorfaktor penghambat kurangnya minat masyarakat dalam melakukan pemeriksaan IVA dan peneliti selanjutnya dapat menambahkanfaktor-faktor lain yang dapat mempengaruhi perilaku WUS untuk melakukan pemeriksaan IVA

\section{DAFTAR PUSTAKA}

1. Samadi, Priyanto.. Yes, I Know Everything About Kanker Serviks.Solo: PT Tiga Serangkai Pustaka Mandiri;2011

2. VOA Indonesia.Tim Peneliti AS Kembang kan Vaksin Untuk Obati Kanker Leher Rahim; 2013. (online), (http:www .voaindo nesia.com /content diakses 1 Oktober 2017).

3. Nurcahyo. Awas Bahaya Kanker Rahim dan Kanker Payudara. Yogyakarta: Wahana Totalita; 2013 
Available Online at http://journal.umgo.ac.id/index.php/madu

4. Departemen Kesehatan. Profil Kesehatan Indonesia; 2010. (online), (http://depkes.go.id diakses 19 September 2017).

5. Riskesdas. Badan Penelitian dan Pengem bangan Kesehatan Kementerian Kesehatan RI; 2013

6. Dinkes Sulsel. Profil Kesehatan Provinsi Sula wesi Selatan; 2012 (online), (http://dinkes.sulselprov.go.id diakses 28 September 2017).

7. Afiyanty, Yati, Pratiwi Anggi. Seksualitas dan Kesehatan Reproduksi Perempuan. Jakarta: PT Raja Grafindo Persada; 2016

8. Utami NM. Hubungan Tingkat Penge tahuan Dengan Perilaku Deteksi Dini Kanker Serviks Pada Pasangan Usia Subur Di Wilayah Kerja Puskesmas Sangkrah Kelurahan Sangkrah Kecamatan Pasar Kliwon Surakarta. Naskah Publikasi: Universitas Muhammadiyah Sura karta; 2013

9. Dinas Kesehatan Kabupaten Gowa. Profil Kese hatan Kabupaten Gowa2015; 2016 (online), http://gowa kab.go.id diakses 29 November 2017).

10.Lestari, Ayu Mustika. Hubungan Pengetahuan dan Sikap WUS dengan Peilaku Pemeriksaan IVA di Kelurahan Kotabaru Wilayah Kerja Puskesmas Gondokusuma II Yogyakarta. Naskah Publikasi: Fakultas Ilmu Kesehatan Universitas „Aisyiyah Yogyakarta; 2015

11. Silfia NN. Hubungan Karakteristik, Pengetahu an dan Sikap dengan Pemeriksaan Inspeksi Visual Asam Asetat (IVA) Pada Ibu Pasangan Usia Subur di Puskesmas Talise. Naskah Publikasi: Poltekkes Kemenkes Palu; 2017

12. Pertiwi, N. D. E. Faktor-faktor yang Berhubu ngan dengan Kunjungan Pemeriksaan IVA pada Ibu-Ibu PKK di Dusun Tajem Depo Sleman. Skripsi Publikasi. Program Studi Bidan Pendidik Jenjang D. IV STIKes Aisyiyah Yogyakarta; 2015

13. Notoadmodjo, S. Promosi Kesehatan dan Peri laku Kesehatan. Jakarta:Rineka Cipta; 2012

14. Dewi, L. Faktor-faktor yang Berhubu ngan Dengan Perilaku Wanita Usia Subur Dalam
Deteksi Dini Kanker Serviks Dengan Metode PemeriksaanInspeksi Visual Asam Asetat (IVA) Di Wilayah Kerja Puskesmas Tanjung Hulu Pontianak Timur. Naskah Publikasi: FK UTP; 2014

15. Mayrita, SN. Hubungan antara Paritas dengan Kejadian Kanker Serviks di Yayasan Kanker Wisnuwardhana Surabaya. Surabaya : UNUSA; 2015

16. Ina Amma. Budaya "Siri' Na Pacce" dan Arus Modernisme (Perspektif Agama dan Budaya); 2016 (Online) (http://www.realitas news .info diakses 9 Juli 2018).

17. Omposunggu F, Evi Karota Bukit. Karakteristik, Hambatan Wanita Usia Subur Melakukan Pap Smear di Puskesmas Kedai Durian. Sumatera Utara : Fakultas Keperawatan, Universitas SumateraUtara; 2013 